\title{
Model of the Organization of the Blended Learning in the Translation of Business Correspondence on the Basis of Electronic Educational Resources
}

\author{
Liliya R. Nizamieva, Gulnara I. Nazarova, Elena K. Kuzmina, Gérard Broussois
}

\begin{abstract}
The article is devoted to the description and analysis of the implementation model of modern educational technologies of blended learning in the process of professional training of specialists in foreign languages. These technologies act as a means of stimulating motivation, cognitive independence and activity of students. Their use increases the efficiency of the educational process by changing the models of interaction of its participants. At the same time, students make the transition from traditional passive perception of the material to its active development thanks to the capabilities of the virtual learning environment, which allows them to build their own learning path and consciously master the learning information. The advantage of blended learning is a more appropriate distribution of study time, high adaptability and interactivity, a deeper understanding and analysis of program material by students. The appropriateness of the application of educational technologies of blended learning was analyzed on the example of studying the course "Theory and Practice of Translation of Epistolary Texts (French)" by students of Kazan Federal University. The material for testing was an electronic educational resource developed specifically for the development of this educational discipline. An analysis of the results of the pilot training shows that the introduction of these technologies increases the significance and effectiveness of the educational process due to its individualization and differentiation, and also develops the creative thinking of students, forms their responsibility and ability to self-management.
\end{abstract}

Keywords: forms of training organization, blended learning, virtual learning environment, learning management system, cognitive independence, teaching foreign languages, translation of business correspondence.

\section{INTRODUCTION}

Currently, the structure, forms of organization, as well as methods and technologies for the professional training of university graduates are undergoing constant changes. This is due to a change of orientation in the field of education in accordance with the increasing level of socio-economic development of countries, breaking of traditional stereotypes, erasing national barriers and integration into the world educational space, characterized by the widespread use of digital technologies to more effectively master the

Revised Manuscript Received on November 08, 2019.

* Correspondence Author

Liliya R. Nizamieva ${ }^{1}$, ${ }^{1}$ Kazan Federal University

Gulnara I. Nazarova ${ }^{1}$, ${ }^{1}$ Kazan Federal University

Elena K. Kuzmina ${ }^{1},{ }^{1}$ Kazan Federal University

Gérard Broussois, Ministry of National Education, Higher Education and Research ever-growing volume of new knowledge in the context of development of a modern information society.

The search for the most effective ways of organizing the educational process has led researchers from different countries to study in more depth the causes of the failure of traditional forms of education in modern conditions that require quick adaptation of the content and methods of education to constantly changing social needs [Carneiro et al., 2010; Farkhaeva et al., 2016]. In this regard, alternative forms of organizing an interactive educational process have come to the fore, among which is blended learning, combining the advantages of both full-time education with the participation of a teacher and training using digital resources [Dufour, 2014; Abdullina et al., 2019].

The term "blended learning" was first proposed by the American Interactive Learning Center in 1999, however, the principles of this technology were laid down in the sixties of the XX century. The first clear definition of the term refers to 2006: "blended learning environments combine traditional face-to-face instruction with computer mediated or on-line instruction" [Bonk, Graham, 2006]. In the process of expanding research in this area, a number of synonyms for this term have appeared: "hybrid learning", "technology-mediated instruction", "web-enhanced instruction", "mixed-mode instruction".

\section{METHODS}

Currently, blended learning is an educational technology based on the mixing and interpenetration of full-time and e-learning. It combines traditional classroom work with the involvement of information technology for self-development and consolidation of educational material [Frydrychova Klimova, 2011]. The alternation of individual stages and the general distribution of study time between traditional and e-learning are determined by the goals and objectives of the training, the specifics of the material studied, the individual characteristics and educational needs of the students. In this case, e-learning is built on the basis of specially developed or selected electronic educational resources of the Internet or interactive virtual learning platforms [Varlamova et al., 2016; Bergmann, Smith, 2017; Somasundram, et al 2019].

So, how is blended learning tested and used in the educational process of Kazan Federal University as part of the development of the constituent elements of the educational platform MOODLE (Modular Object-Oriented Dynamic Learning Environment) 
distance learning edu.kpfu.ru? It is a virtual learning environment that hosts electronic resources in multiple subjects, and which acts as an automated learning management system [Sharipova et al., 2017; Kord, et al 2017; Galvão \& Henriques, 2018; Kabayeva, et al 2018].

Teaching French as the first foreign language in "Pedagogical Education" at the undergraduate level implies mastering a number of linguistic disciplines by students, among which there are translation courses specializing in economics and business foreign language. One of such subjects is the course of translating epistolary texts, in support of which the corresponding electronic educational resource was developed on the MOODLE KFU platform, which served as the material for this study. As research methods, we used the study and generalization of pedagogical experience, observation of the educational process, testing, questionnaires, experimental training and analysis of the results of educational activities.

\section{RESULTS AND DISCUSSION}

During the course of epistolary translation, students acquire knowledge and skills in French-Russian translation of private and business correspondence. Along with other linguistic disciplines, the course provides the formation of foreign language communicative competence, deepening the general cultural horizons and general philological training of students [Kuzmina et al., 2018; Andrianova et al., 2018]. The course covers the study of lexicological, grammatical, and stylistic questions of the translation of the main types of written documents of the epistolary genre such as summaries, motivation letters, cover letters, notification letters, offer letters and answers to offers, letters of request, reminders, documentation on the execution and confirmation of orders, invoices and specifications, complaints and responses to complaints, short messages and emails, memos and announcements.

The electronic course is designed for both classroom and independent work, as it contains detailed guidelines for students. The theoretical provisions contained are devoted to such topics as: genre épistolaire, correspondance professionnelle et privée, le CV et la lettre de motivation, la télécopie et la lettre commerciale, les lettres d'offre et de passation de la commande, d'avertissement et de réclamation, courriels et messages. The theoretical part of the course is framed in the form of texts of lectures and presentations to them. A glossary of basic concepts and definitions provided for each topic, as well as questions for self-monitoring, allow students to repeat and consolidate the material studied, to prepare for the implementation of practical tasks and tests in separate blocks.

In addition to the main and additional literature, including from publicly available electronic sources, for a deeper study of certain aspects of the topic, as training materials, the blocks of the course include tasks for independent work from Internet resources, such as: maildesigner.com, modele-lettre.com, visezjuste.uottawa.ca, calliope.be, journaldunet.fr, merci-facteur.com, bonjourdefrance.com. The proposed tasks are aimed, in particular, at the development of various formulas of politeness, traditionally used in correspondence in French, and their contextual conditionality. There are also tasks to study the structural features of the organization of business texts in accordance with the norms adopted in international practice, tasks to eliminate lexical, grammatical and stylistic errors in the text formatting of documents.

The control of the level of mastering the course material is carried out on the basis of the final test task for which a limited amount of time has been allocated and which provides for only one attempt to pass.

The development of materials for the electronic resource started in 2016, the course was launched in 2017, so far about 100 students have completed training on this technology. The course is taught in the third year of study under the undergraduate program, it is highly adaptive and can be applied in the context of constantly changing curricula, redistribution or reduction of hours for class work. Table 1 shows the hours allocated for its development in accordance with the curriculum of undergraduate recruitment 2016-2019.

Table 1 The number of hours in "Theory and practice of translating epistolary texts (French)"

\begin{tabular}{|l|c|c|c|c|}
\hline $\begin{array}{l}\text { Undergraduate } \\
\text { curriculum }\end{array}$ & $\mathbf{2 0 1 6}$ & $\mathbf{2 0 1 7}$ & $\mathbf{2 0 1 8}$ & $\mathbf{2 0 1 9}$ \\
\hline Lectures & 0 & 0 & 8 & 8 \\
\hline Practical lessons & 18 & 16 & 8 & 8 \\
\hline $\begin{array}{l}\text { Independent } \\
\text { work }\end{array}$ & 18 & 20 & 20 & 20 \\
\hline Total hours & 36 & 36 & 36 & 36 \\
\hline
\end{tabular}

Starting the course "Translation of Epistolary Texts", students first of all receive a password for access to the electronic educational resource and sign in. During the first lesson, the teacher presents the thematic plan and the work program of the academic discipline to students, explains the goals and objectives of the educational course, and also provides detailed guidelines for working with it.

During the course, first of all, the basic theoretical positions of the studied block are considered. This work can be built both according to the traditional type, and according to the Flipped classroom technology of blended learning, when students preliminarily independently study the training material prepared by the teacher, and then, in the process of classroom work, in joint discussion with the teacher, they analyze the most complex theoretical questions and problems , summarize the key provisions of the topic. After competing the theoretical block, students are offered to first test their knowledge by answering questions for self-control, and then perform control thematic tests on the material studied. The tests provide for various types of tasks; they are evaluated immediately after their completion on-line. Each student is informed not only of their score but also the correct answers to questions they could not cope with. For its part, the teacher monitors the results of each student in a timely manner and provides additional assistance to those who are experiencing difficulties.

After mastering the theoretical provisions of the topic the students proceed to practical tasks of various types (preparatory and proper translation). In preparation for practical assignments for translation, the internal and external form of the text, i.e. general typical structure of the document to be translated. Its features are analyzed in terms of vocabulary, grammar and stylistics, the composition and density of the information presented in it, the communicative intention of the 
author, which forms the basis of the pre-translation analysis of the text, which determines the strategy for its subsequent translation, including the choice of language tools, the use of translation transformations and the preparation of the final document. Translation exercises themselves are time-consuming for implementation, therefore, students do them in the process of independent work in extracurricular time. Works are sent to the teacher for verification. The course provides for feedback forms with students through thematic forums, sending messages, comments and works verified by the teacher to the email addresses of users.

As a result of mastering the course, students should master the principles and models of translation, the basic translation transformations, types of equivalence in translation, methods and techniques of translation. The study of the discipline is aimed at leading students to an understanding of the tasks and the role of translation as one of the types of interlanguage and intercultural mediation, to understanding the features of translation activity in modern conditions. They must learn to develop a holistic translation strategy with the consideration of the semantic content of the text, its functional-style characteristics, genre affiliation, as well as taking into account the purpose, destination of the translation and other extralinguistic factors. The development of the course also contributes to the formation of students' linguistic and linguistic competencies, the development of abstract thinking, the skills of analysis and synthesis of information, the ability to improve and develop their intellectual and cultural level.

The effectiveness of the application of blended learning is evidenced by the results obtained experimentally in the process of testing an electronic educational resource in the educational process of a university. The average indicator for the results of the test control of mastery of theoretical material was 7.72/10 points for all participants. The average score for the implementation of practical tasks $-7.07 / 10$. The average score for completing the final control test is $15.26 / 20$. The final grade for the course ranges from $48.87 / 100$ to $95.28 / 100$ points, while the average for all students is $74.85 / 100$ points.

\section{SUMMARY}

Thus, the creation of an adaptive learning environment based on blended learning technology ensures the efficiency of the educational process, increases the motivation and responsibility of students for the results of their activities. This is facilitated by the interactivity achieved by expanding the communication field of interpersonal interaction (opportunities are provided for both direct and indirect communication with the teacher and other participants). Interactive interaction with content, characterized by a variety of forms of information provision, ensures differentiation and individualization of training [Rachimova et al., 2016; Klimova, 2017; Rivera, 2019]. A high degree of individualization of the educational process allows students to build their own trajectories of personal and professional growth, taking into account their cognitive interests, educational needs, as well as the most suitable learning style.

\section{CONCLUSIONS}

The use of blended learning technologies in teaching foreign languages allows changing the traditional educational strategy, characterized by the predominance of frontal forms of classroom work, leaving the learner insignificant opportunities to play an active role as an independent subject of the educational process.

The development of models of interaction between the subjects of the educational process leads to a change in the functions performed by the teacher and the trainees in the process of joint educational activity, to a reorientation of its focus and redistribution of roles. The student becomes an active participant in the learning process, responsible for its results, which entails changes in the ways of activity. The freedom provided to the student and the possibility of a conscious choice of the learning path provide increased motivation and interest not only as a result, but also in the process of his activity, leading the student to a conscious selection of means and methods of achieving this result.

A variety of activity forms of work with educational content enhances the practical orientation of modern education and the development of activity, independence, and creative potential of students. An increase in the share of research and effective practical work leads to the development of initiative and creative thinking, the formation of the individual's ability to flexibly adapt to new situations and carry out their activities based on the application of the existing knowledge and acquired professional competencies.

Thus, blended learning represents a very promising approach to learning, able to determine the direction of modernization of all levels of education because their goal is further creative development and self-education of the individual.

\section{ACKNOWLEDGMENTS}

The work is performed according to the Russian Government Program of Competitive Growth of Kazan Federal University.

\section{REFERENCES}

1 Carneiro, R., Lefrere, P., Steffens, K., Underwood, J. (2011). Self-Regulated Learning in Technology Enhanced Learning Environments. Rotterdam: Sense Publishers. 31 p.

2 Farkhaeva, A.I., Fazlyeva, Z.Kh., Sheinina, D.P. (2016). Computer Technologies in Assistance to Second Language High School Study // Modern Journal of Language Teaching Methods. 6(8). P. 70-75.

3 Dufour, H. (2014). La classe inversée // Technologie. No193, septembre-octobre 2014. P. 44-47.

4 Abdullina, L.R, Ageeva, A.V, Gabdreeva, N.V. (2019). Using the "Flipped classroom" model in the teaching of the theoretical disciplines (French language) at the university [Technologie de la classe inversée dans l'enseignement des disciplines théoriques (FLE) aux étudiants des universités] // XLinguae. Vol.12. Is.1XL. P. $161-$ 169.

5 Bonk, C.J., Graham, C.R. (2006). Handbook of blended learning: Global Perspectives, local designs. San Francisco, CA: Pfeiffer Publishing. $624 \mathrm{p}$.

6 Frydrychova Klimova, B., Hubackova, S., Semradova, I. (2011) Blended learning in a foreign language learning // Procedia Soc. Behav. Sci. 28. P. 281-285.

7 Varlamova, M.Yu, Bochina, T.G, Miftakhova, A.N. (2016) Interactivity in teaching a foreign language // Journal of Language and Literature. 7(3). P. 190-194.

8 Bergmann, J., Smith, E. (2017). Flipped Learning 3.0: The Operating System for the Future of Talent Development. Chicago IL: FLGlobal. 248 p.

9 Sharipova, D.Y., Khuziakhmetov, A.N., Nasibullov, R.R, Yarullin, I.F. (2017). Improving the quality of professional training of students in the distance learning // Man in India. 97(3). P. 401-416. 
10 Kuzmina, E.K, Nazarova, G.I, Nizamieva, L.R, Leblanc, C. (2018). Innovative technologies of teaching business French // International Journal of Engineering and Technology (UAE). 7(4). P. 85-87.

11 Andrianova, N.S., Vassilieva, V.N., Ostroumova, O.F., Broussois, G. (2018). Integrative Use Of Modern Technologies For Teaching Foreign Languages // Modern Journal of Language Teaching Methods. 8(10). P.271-275.

12 Rachimova, A.E, Varlamova, E.V, Tulusina, E.A. (2016). Advantages of computer technologies use in training in foreign languages at the present stage of an education system modernization // Modern Journal of Language Teaching Methods. Special Issue (December 2016). P. 97-101.

13 Klimova, B. (2017). Evaluation of the Blended Learning Approach in the Course of Business English - A Case Study // Huang TC., Lau R., Huang YM., Spaniol M., Yuen CH. (eds) Emerging Technologies for Education. SETE 2017. Lecture Notes in Computer Science, vol 10676. Springer, Cham. DOI: https://doi.org/10.1007/978-3-319-71084-6_37.

14 Rivera, J. (2019). Blended Learning-Effectiveness and Application in Teaching and Learning Foreign Languages // Open Journal of Modern Linguistics. 9. P. 129-144. DOI: 10.4236/ojml.2019.92013.

15 Kord, H., Noushiravani, Y., Bahadori, M. D., \& Jahantigh, M. Review and Analysis of Telework Perspective in the Administrative Systems. Dutch Journal of Finance and Management, 1(2), (2017).44. https://doi.org/10.29333/djfm/5820

16 Galvão, M., \& Henriques, R. Forecasting Movie Box Office Profitability. Journal of Information Systems Engineering \& Management, 3(3), (2018). 22.

17 Somasundram, P., Akmar, S. N., \& Eu, L. K. Pattern Generalisation by Year Five Pupils. International Electronic Journal of Mathematics Education, 14(2), 353-362. https://doi.org/10.29333/iejme/5719

18 Kabayeva, Z., Mussabaev, S., \& Madalieva, Z. The formation way of independent Kazakhstan from the individualism and collectivism perspective. Opción, 34(85-2), (2018).706-728. 